\title{
Pathogenesis of Infectious Coryza in Chickens (Gallus gallus) by Avibacterium paragallinarumn Isolate of Bangladesh
}

\author{
M. Ali, M. S. Hossain, S. Akter, M. A. H. N. A, Khan and M. M. Hossain* \\ Department of Pathology, Faculty of Veterinary Science, Bangladesh Agricultural University, \\ Mymensingh-2202, Bangladesh
}

*Corresponding author and Email: mmhossain04@yahoo.com.au

Received: 3 September $2012 \quad$ Accepted: 18 May 2013

\begin{abstract}
An investigation was conducted to isolate and identify the causal agent of infectious coryza (IC) with pathogenesis study by local isolate of Avibacterium paragallinarum in chicks in Bangladesh. One isolate of A. paragallinarum was used to study the experimental pathogenesis. For this, 14 days old 24 chicks were grouped into two (A and B) and each group contained 12 birds. Chicks of group A were inoculated with $1 \mathrm{ml}$ of 2 days old nutrient broth and were kept as control group while group B were inoculated with $1 \mathrm{ml}$ of 2 days old culture broth of A. paragallinarum. To study the pathology, 4 birds from each group were sacrificed on day 3, 5 and 7 of post inoculation. Sacrificed birds of group A did not reveal any clinical sign and lesion. Chicks of group B showed mild nasal discharge, conjunctivitis, depression and inability to move. The gross lesions of the chicks of group B included mucous in nasal passage, conjunctivitis, swelling of sinuses and face and congested lungs. The microscopic lesions of the chicks of this group were acanthosis and congested blood vessels of nasal passage, pneumonic lesion of lung, focal hepatitis of liver and fatty change and lipid nodules in macrophages of heart which were progressively prominent on day 7 of bacterial inoculation. $A$. paragallinarum was reisolated from day 7 of post inoculation (PI) from nasal passage of chicks in which lesions were prominent. The proposed experimental pathogenesis was after intranasal inoculation with $A$. paragallinarum, rhinitis developed, bacteria entered into blood, reached different organs producing lesions. The lesions which are discussed here (rhinitis in association with focal hepatitis, fatty change in heart with lipid granuloma, progressive pneumonic lesions) are not usually present in adult and young birds.
\end{abstract}

\section{Keywords: Pathogenesis, infectious coryza, chicks, Avibacterium paragallinarum}

\section{Introduction}

Infectious coryza is an acute respiratory disease in chickens (Gallus gallus). The disease has worldwide economic recognition and causes infection in both broiler and layer flocks. The disease has a low mortality rate but leads to a drop in egg production up to $40 \%$ in layer hens and increased culling in broilers and thus poses significant financial liability to chicken farmers (Mouahid et al., 1992). The disease is caused by gram negative bacteria $A$. paragallinarum. Clinically, the disease is characterized by rapid onset and high morbidity in flock, decreased feed consumption, decreased egg production, oculonasal conjunctivitis, edema of the face, respiratory noise, swollen infraorbital sinus, and exudates in the conjuncivital sac (Eaves et al., 
1989). Respiratory sign of infectious coryza persists for a few weeks if complicated by fowl pox, Mycoplasma gallisepticum, Newcastle disease, infectious bronchitis, pasteurellosis and infectious laryngotracheitis (Yamamoto, 1972; Sandoval et al., 1994). So, certainly it has a huge negative impact in poultry industry.

Clinically and grossly, the disease was diagnosed as infectious coryza in Bangladesh (Talha et al., 2001) but the causal agent was not identified. The confirmatory diagnosis of the disease in poultry of Bangladesh is inevitable. Pathological study on the disease, isolation and identification of the causal agent; and study of pathogenesis by local isolate of this bacterium in experimental bird will enrich the knowledge to identify the disease rapidly and that will reflect the prevention and control measures of the disease. A local isolate of $A$. paragallinarum was isolated and identified (Akter, 2012), and the present study was undertaken using this isolate to study the pathogenesis of the disease in experimental chicks.

\section{Materials and methods}

\subsection{Organism}

Local isolate of $A$. paragallinarum was received from Akter (2012) of the Department of Pathology, BAU, Mymensingh. For the growth of $A$. paragallinarum in artificial media, the colony of Staphylococcus aureus is needed to supply NAD required for $A$. paragallinarum. A. paragallinarum was cultured in blood agar media in association with $S$. aureus colonies.

\subsection{Inoculum preparation}

One single colony of $A$. paragallinarum was picked up from blood agar and placed in $250 \mathrm{ml}$ of nutrient broth and cultured for 48 hours. Inoculation dose of $A$. paragallinarum ( $1 \mathrm{ml} /$ bird) was prepared (Islam, 2010) for inoculation on14 days old chicks.

\subsection{Experimental design}

A total of 24 (day 1 old) chicks of cobb 500 broiler chicks were collected and equally divided into two groups ( $\mathrm{A}$ and $\mathrm{B}, \mathrm{N}=12$ ). On day 14 of age, the chicks of group A were inoculated with pure nutrient broth whereas the chicks of group B were inoculated with $A$. paragallinarum at the dose rate of $1 \mathrm{ml}$ inoculum/bird (Islam, 2010) through the intranasal route. Clinical signs observation, reisolation of $A$. paragallinarum and pathological study were performed at interval of day 3, 5 and 7. At each time, 4 birds were sacrificed. Different tissues were collected for histopathology in $10 \%$ formalin on day 3,5 and 7 of post inoculation.

\subsection{Gross lesion study}

All the internal organs including nasal passage were examined and gross lesions were recorded. The inflammatory lesions of different organs (congestion, hemorrhage, swelling, mucus, etc.) were graded as $\pm=$ almost absence of lesion, $+=$ mild lesion, $++=$ moderate lesion and $+++=$ severe lesion.

\subsection{Histopathological study}

Decalcification of nasal bone, processing of tissues and routine $\mathrm{H} \& \mathrm{E}$ staining were performed following the procedures described by Luna (1968). The histopathological lesions (congestion, hemorrhage, necrosis, extent of lesions, inflammatory cells etc.) in different organs were graded as $\pm=$ almost absence of lesion, $+=$ mild lesion, $++=$ moderate lesion and $+++=$ severe lesion.

\subsection{Re-isolation of Avibacterium paragallinarum}

Re-isolation of A. paragallinarum was performed from nasal passage at day 7 of PI where prominent rhinitis was found following the procedures followed by Akter (2012).

\section{Results and Discussion}

\subsection{Clinical findings of chickens}

Clinical signs were observed for last 7 days and samples were collected at different times on day 
3, 5 and 7. Birds of group A (without $A$. paragallinarum) did not reveal any striking clinical sign and lesion. Chicks of group B (inoculated with $A$. paragallinarum) showed different clinical signs that resemble to infectious coryza which were mild nasal discharge, conjunctivitis, depression and inability to move. Similar findings were reported by many investigators (Akter, 2012; Blackall 1989; Page, 1962).

\section{2. Gross study}

The results of gross study have been presented in Table 1 and Fig. 1 \& 2. Chicks of group A (without $A$. paragallinarum) did not reveal any lesion related to the IC on day 3,5 and 7. On the other hand, the chicks of group B (inoculated with $A$. paragallinarum) revealed lesions in different organs following bacterial inoculation which were progressively massive. The gross lesions of the chicks of group B (inoculated with A. paragallinarum) included mucous in nasal passage, conjunctivitis, swelling of sinuses and face and congested lungs. The gross lesions recorded in this investigation corresponded with the findings of other authors (Akter, 2012; Talha et al., 2001; Blackall 1989; Yamamoto, 1972; Page, 1962).

\section{3. Histopathological study}

Twenty four nasal passages from 24 slaughtered chicks were processed for histopathology. Twelve samples (four on day 3, four on day 5 and four on day 7) from group B were diagnosed as lesions of infectious coryza after histopathological studies. All of the microscopic lesions have been presented in Table 2 and illustrated in Fig. 3-10. The microscopic lesions of the chicks of this group were acanthosis and congested blood vessels of nasal passage and pneumonic lesion of lung which were progressively prominent on day 7 of bacterial inoculation. All of these studies have very close agreements with studies of Sawata et al. (1985) and Droual et al. (1990) who studied the microscopic changes due to infectious coryza.

\section{4. Reisolation of Avibacterium paragallinarum at day 7 of post inoculation}

Reisolation was performed only in tissues showing pathological lesions i.e. found on day 7 of post inoculation (PI). Only 4 samples were processed for reisolation. A. paragallinarum was reisolated from day 7 of post inoculation (PI) from nasal passage of chicks in which lesions were prominent.

\section{5. Gram's stain, biochemical tests, Sugar fermentation test and catalase activity test}

Tentatively identified colonies of $A$. paragallinarum from nasal passage of day 7 of PI from blood agar media were stained with Gram's stain. Samples showed Gram- negative, red color, rod shaped bacilli arranged as single or paired (Akter, 2012) (Fig. 11). In Gram's staining, the morphology of the isolated bacteria exhibited pink or red (Gram's stain color) small rod shaped Gram negative coccobacilli. These findings agreed with those reported by several other authors (Sameera et al., 2001; Yamamoto, 1991; Sawata et al., 1980; Jaswinder et al., 2004). A. paragallinarum isolate was able to ferment four basic sugars by producing acid. Al1the isolates fermented glucose, sucrose maltose, mannitol but failed to ferment galactose within 21h-48h of incubation (Blackall 1989; Hinz and Kunjara, 1977) (Fig. 12).

\section{Conclusions}

The pathogenesis study after intranasal inoculation with $A$. paragallinarum, rhinitis developed, bacteria entered into blood, reached different organs producing lesions. The lesions that we discussed here (rhinitis in association with focal hepatitis, fatty change in heart with lipid granuloma, progressive pneumonic lesions) are not usually present in adult and young birds. This may be a new finding of this disease. However, it needs further investigation. 
Table 1. Gross lesions in different organs in infectious coryza

\begin{tabular}{|c|c|c|}
\hline Groups & $\begin{array}{l}\text { Day after } \\
\text { inoculation }\end{array}$ & Gross lesions \\
\hline \multirow{2}{*}{$\begin{array}{l}\text { Group A (control } \\
\text { group) }\end{array}$} & 3 & Nasal passage and other internal organs $=( \pm)$ \\
\hline & $\begin{array}{l}5 \\
7\end{array}$ & $\begin{array}{l}\text { Nasal passage and other internal organs }=( \pm) \\
\text { Nasal passage and other internal organs }=( \pm)\end{array}$ \\
\hline \multirow{3}{*}{$\begin{array}{l}\text { Group B (inoculated } \\
\text { with } A \text {. } \\
\text { paragallinarum) }\end{array}$} & 3 & Mucous in nasal passage $=(+)$ \\
\hline & 5 & $\begin{array}{l}\text { Mucous in nasal passage }=(+) \\
\text { Tracheal hemorrhage }=(+)\end{array}$ \\
\hline & 7 & $\begin{array}{l}\text { Mucous in nasal passage }=(++) \\
\text { Conjunctivitis }=(+ \text { to }++) \\
\text { Swelling of sinuses and face }=(+ \text { to }++) \\
\text { Congested and pneumonic lungs }=(+ \text { to }++)\end{array}$ \\
\hline
\end{tabular}

$\pm=$ almost no inflammatory lesion, $+=$ mild inflammatory lesion,

$++=$ moderate inflammatory lesion related to IC

Table 2. Results of histopathological studies of group B (inoculated with A. paragallinarum)

\begin{tabular}{|c|c|c|c|c|}
\hline $\begin{array}{c}\text { Day of } \\
\text { inoculation }\end{array}$ & Nasal passage & Lung & Liver & Heart \\
\hline Day 3 & $\begin{array}{l}\text { Acanthosis of nasal } \\
\text { epithelium, } \\
\text { congested blood vessel, } \\
\text { hyperplasia of mucous } \\
\text { gland (+) }\end{array}$ & $\begin{array}{l}\text { Mild } \\
\text { pneumonic } \\
\text { lesion }(+)\end{array}$ & $\begin{array}{l}\text { Lymphocyte } \\
\text { infiltration } \\
(+)\end{array}$ & $\begin{array}{l}\text { Fatty change and } \\
\text { lipid nodule in } \\
\text { macrophage }(+)\end{array}$ \\
\hline Day 5 & $\begin{array}{l}\text { Acanthosis of nasal } \\
\text { epithelium, } \\
\text { congested blood vessel, } \\
\text { hyperplasia of mucous } \\
\text { gland (+) }\end{array}$ & $\begin{array}{l}\text { Moderate } \\
\text { pneumonic } \\
\text { lesion }(++)\end{array}$ & $\begin{array}{l}\text { Lymphocyte } \\
\text { infiltration } \\
(+)\end{array}$ & $\begin{array}{l}\text { Fatty change and } \\
\text { lipid nodule in } \\
\text { macrophage }(+)\end{array}$ \\
\hline Day 7 & $\begin{array}{l}\text { Acanthosis of nasal } \\
\text { stratified epithelium, } \\
\text { congested blood vessel, } \\
\text { hyperplasia of mucous } \\
\text { glands and necrotic tissue } \\
\text { debris in glands, } \\
\text { presence of inflammatory } \\
\text { cells (++) }\end{array}$ & $\begin{array}{l}\text { Severe } \\
\text { pneumonia } \\
(+++)\end{array}$ & $\begin{array}{l}\text { Focal hepatitis } \\
(++)\end{array}$ & $\begin{array}{l}\text { Fatty change and } \\
\text { lipid nodule in } \\
\text { macrophage }(++)\end{array}$ \\
\hline
\end{tabular}




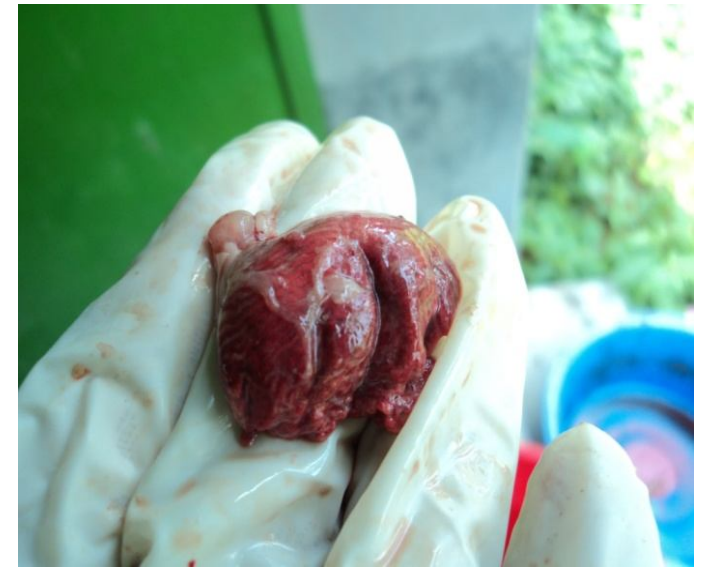

Fig. 1. Severely congested lung of a chicken of group B (inoculated with $A$. paragallinarum) on day 7 of post inoculation

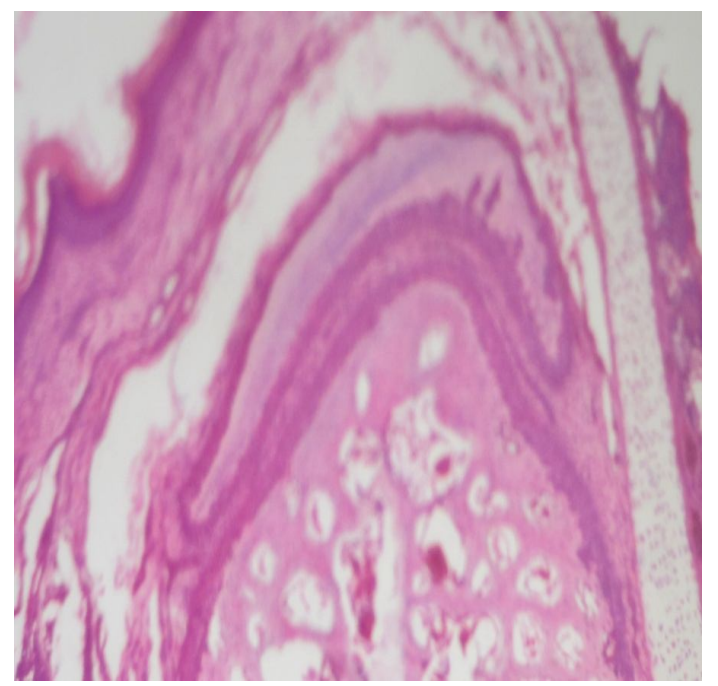

Fig. 3. Nasal passage of group A (inoculated with nutrient broth) on day 7 of post inoculation showing no lesion (H \& E stain, X 333)

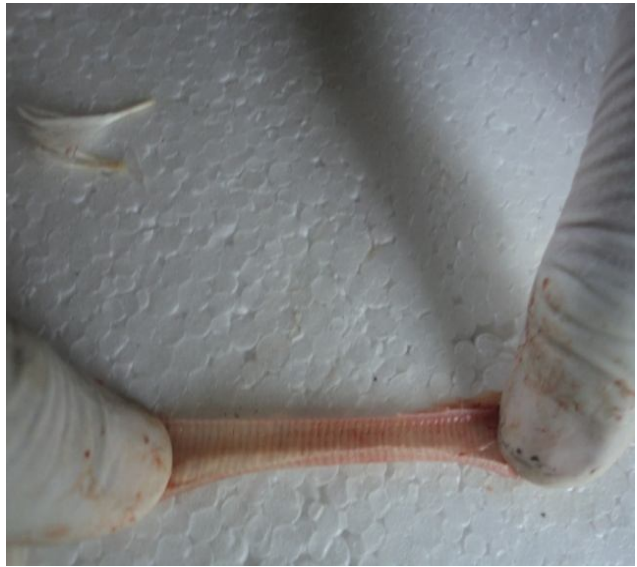

Fig. 2. Mild tracheal haemorrhage of a chicken of group B (inoculated with $A$. paragallinarum) on day 3 of post inoculation

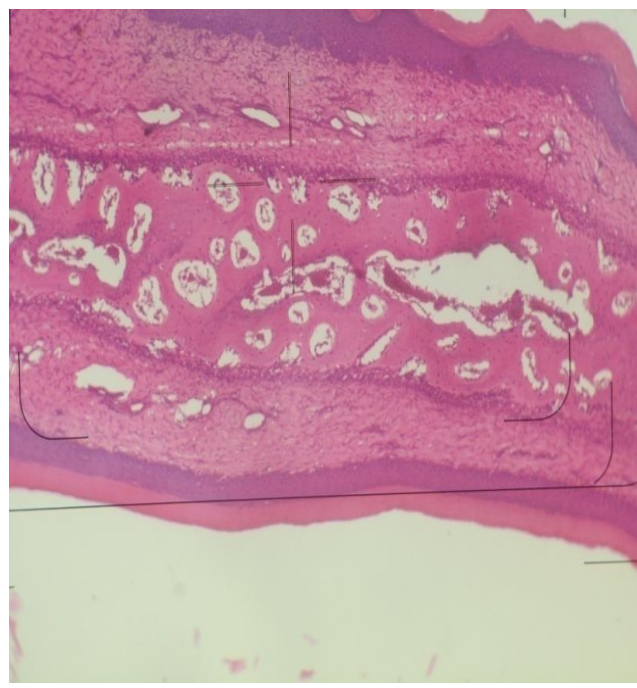

Fig. 4. Nasal passage of group B (inoculated with A.paragallinarum) on day 7 of post inoculation showing acanthosis (arrow), parakeratosis and/mucous ( $\mathrm{H} \& \mathrm{E}$ stain, $\mathrm{X}$ 333) 


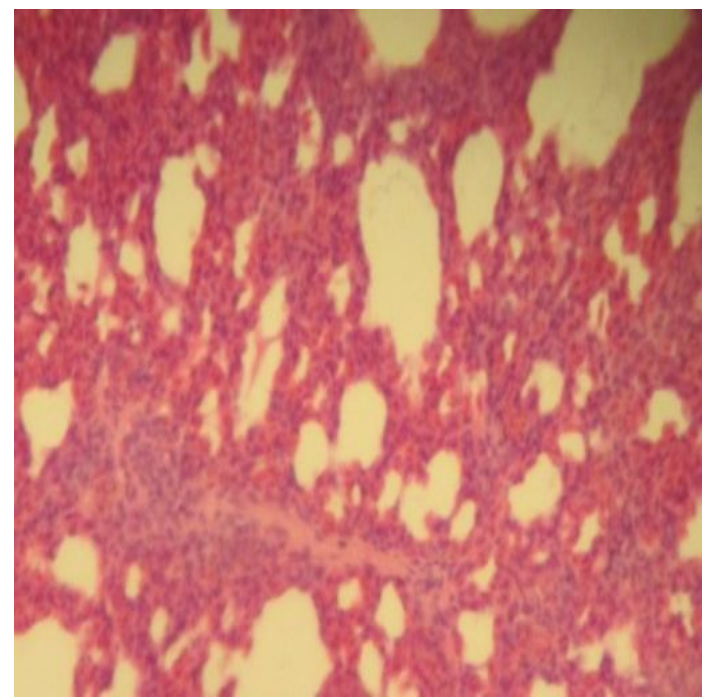

Fig. 5. Section of lung of a chicken of group A (inoculated with nutrient broth) showing no lesion to mild lesion $( \pm$ to +$)$ on day 7 of post inoculation (H \& E stain, X 333)

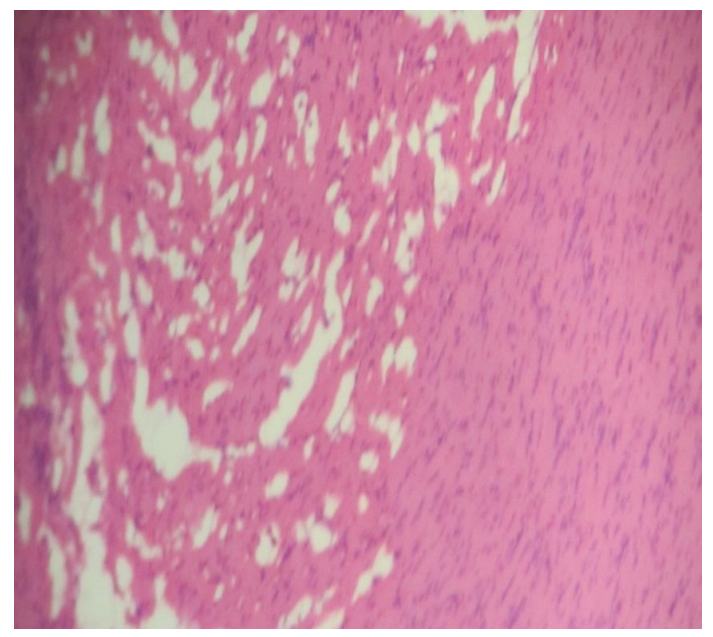

Fig. 7. Fatty change, lipid nodules in macrophages and micronodules in heart of group B (inoculated with $A$. paragallinarum) on day 5 of post inoculation (H \& E stain, X 333)

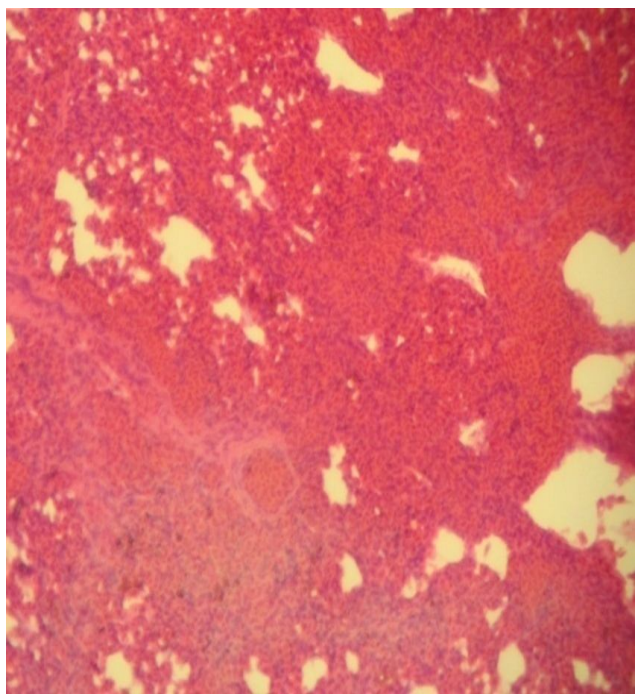

Fig. 6. Lung of group B (inoculated with $A$. paragallinarum) on day 7 of post inoculation showing severe pneumonic lesion $(+++)$ (H \& E stain, X 333)

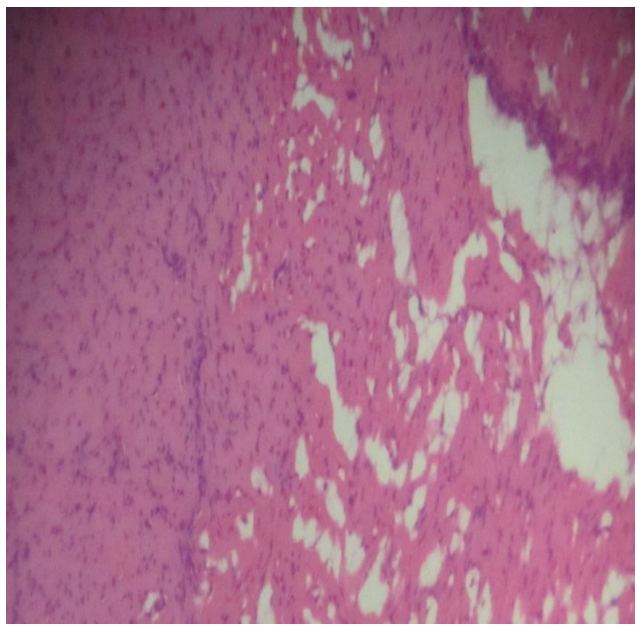

Fig. 8. Fatty change, lipid nodules in macrophages and micronodules in heart of group B (inoculated with $A$. paragallinarum) on day 7 of post inoculation ( $\mathrm{H} \& \mathrm{E}$ stain, $\mathrm{X}$ 333) 

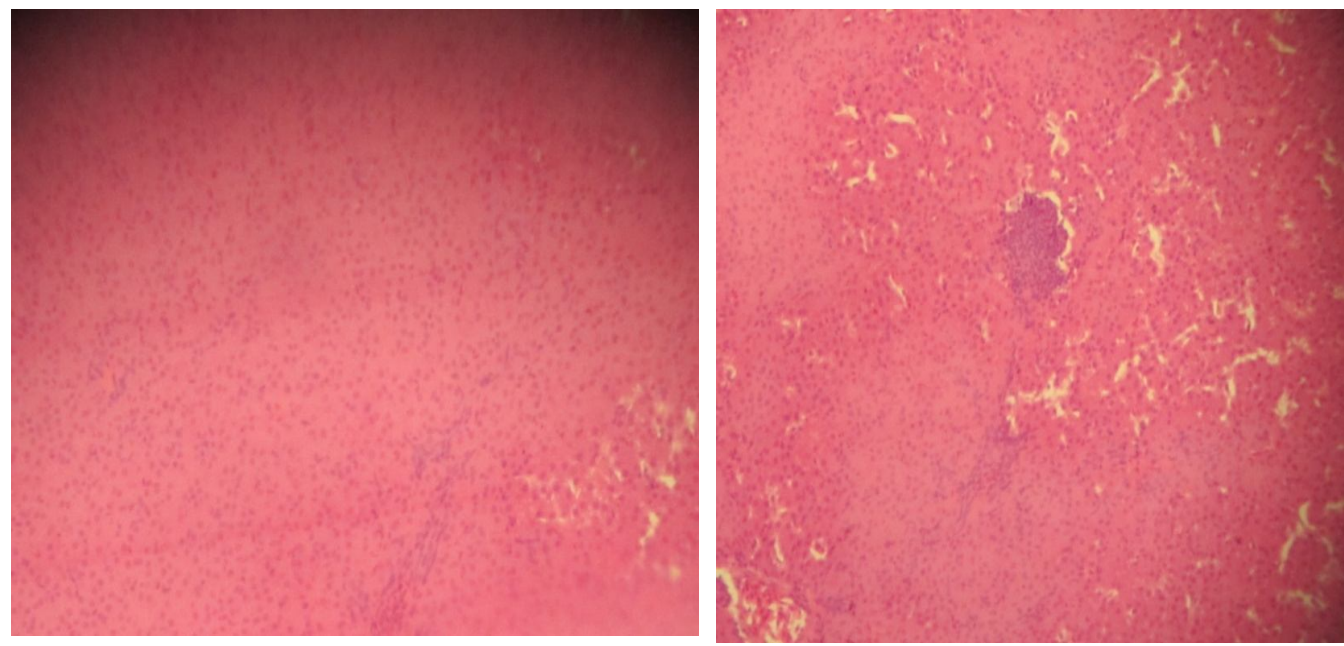

Fig. 9. Liver of group A (inoculated with nutrient broth) on day 7 of post inoculation showing almost no lesion $( \pm)$ (H \& E stain, X 333)

Fig. 10. Liver of group B (inoculated with $A$. paragallinarum) on day 7 of post inoculation showing focal hepatitis (lymphocytes and plasma cell) (H \& E stain, X 333)
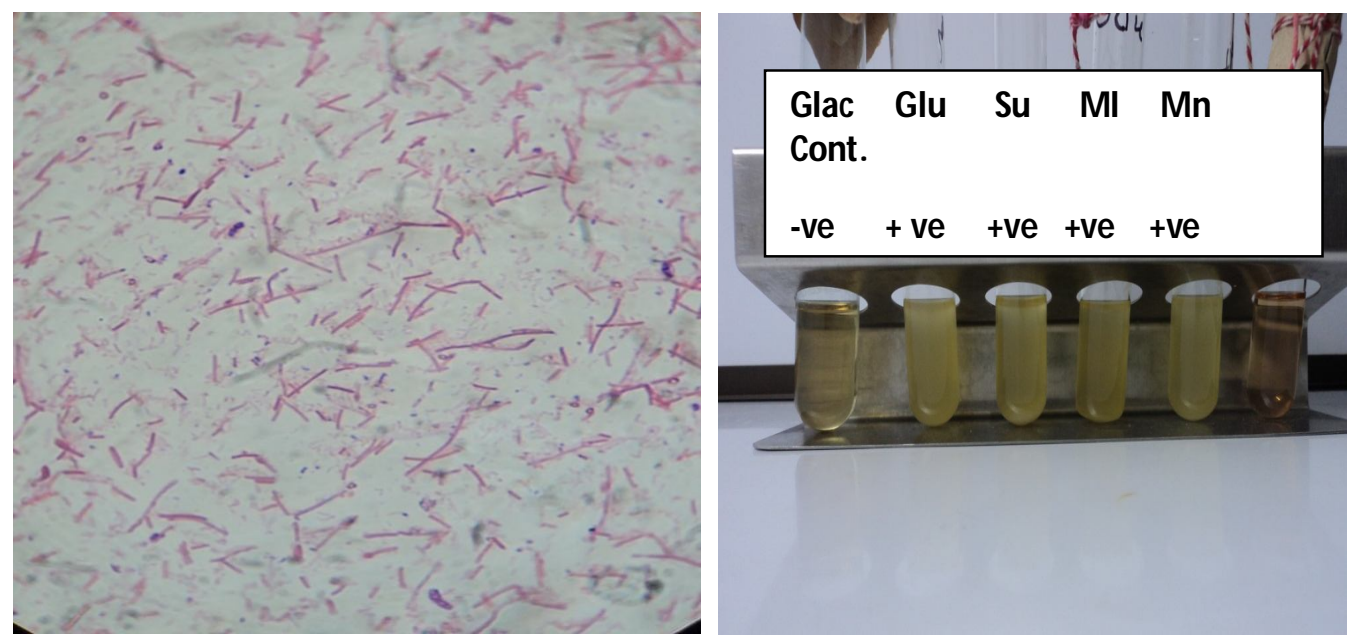

Fig. 11. A. paragallinarum showing gram negative rod shaped bacilli on day 7 (Gram's staining, $\mathrm{X}$ $830)$.

Fig. 12. Fermentation of glucose, sucrose, mannitol, maltose with production of only acid and no fermentation of galactose by $A$. paragallinarum 


\section{Acknowledgement}

The authors are grateful to Bangladesh Agricultural University Research System (BAURES) for financial support to conduct this research (Project No.2011/01/AU-GC).

\section{References}

Akter, S. 2012. Isolation and identification of Avibacterium paragallinarum from layer chickens. MS Thesis Submitted to Department of Pathology, Faculty of Veterinary Science, Bangladesh Bangladesh Agricultural University, Mymensingh-2202.

Blackall, P. J. 1989. The avian haemophili. Clinical Microbiological Review, 2:270277.

Droual, R., Bickford, A. A., Charlton, B. R., Cooper, G. L. and Channing, S. E. 1990. Infectious coryza in meat chickens in the San Joaquin Valley of California. Avian Disease, 34:1009-10016.

Eaves, L. E., Rogers, D.G. and Blackall, P. J. 1989. Comparison of hemagglutinin and agglutinin schemes for the serological classification of Haemophilus paragallinarum and proposal of a new hemagglutinin serovar. Journal of Clinical Microbiology, 27:1510-1513.

Hinz, K. H. and Kunjara, C. 1977. Hemophilus avium, a new species from chickens. International Journal of Systemic Bacteriology, 27:324-329.

Islam, M. S. 2010. Pathogenesis of experimental infection of chickens with field isolate of Clostridium perfingens. MS Thesis Submitted to Department of Pathology, Faculty of Veterinary Science, Bangladesh Bangladesh Agricultural University, Mymensingh-2202.

Jaswinder, K., Sharma, N. S., Gupta, K. and Singh, A. 2004. Epidemiological studies on infectious coryza in chickens in northern India. Indian Journal Animal Science, 74 (5): 462-465.

Mouahid, M., Bisgaard, M., Morley, A. J., Mutters, R. and Mannheim, W. 1992.
Occurrence of V-factor (NAD) independent strains of Haemophilus paragallinarum. Veterinary Microbiology, 31:363-368.

Page, L. A. 1962. Haemophilus infections in chickens. 1. Characteristics of 12 Haemophilus isolates recovered from diseased chickens. American Journal Veterinary Research, 23:85-95.

Sameera, A., Bhatti, A. R. and Muhammad, K. 2001. Clinico-Therapeutic Observations on an Outbreak of Infectious Coryza. International Journal of Agricultural Biology, 03(4):531-532.

Sandoval, V. E., Terzolo, H. R. and Blackall, P.J. 1994. Complicated infectious coryza cases in Argentina. Avian Diseases, 38:672-678.

Sawata, A., Kume, K. and Nakase, Y. 1980. Biologic and serologic relationships between Page's and Sawata's serotypes of Haemophilus paragallinarum. American Journal of Veterinary Research, 41:1901-1904.

Sawata, A., Nakai, T., Kume, K., Yoshikawa, H. and Yoshikawa, T. 1985. Intranasal inoculation of chickens with encapsulated or non-encapsulated variants of Haemophilus paragallinarum: electron microscopic evaluation of the nasal mucosa. American Journal of Veterinary Research, 46:2346-2353.

Talha, A. F. S. M.; Hossain, M. M.; Chowdhury, E. H.; Bari, A. S. M.; Islam, M. R. and Das, P. M. 2001. Poultry diseases occurring in Mymensingh district of Bangladesh. Bangladesh Veterinarian, 18 (1): 20-23.

Yamamoto, R. 1972. Infectious Coryza. In M. S. Hofstad, B. W. Calnek, C. F. Helmboldt, W. M. Reid, and H. W. Yoder, Jr. (eds.). Diseases of Poultry, 6th ed. Iowa State University Press: Ames, IA 272-281.

Yamamoto, R. 1991. Infectious coryza. In B. W. Calnek, H. J. Barnes, C. W. Beard, W. M. Reid, and H. W. Yoder, Jr. (eds.). Diseases of Poultry, 9th ed. Iowa State University Press: Iowa, IA 186-195. 